\title{
INOVASI TEKNOLOGI AIR MINUM BERBASIS MASYARAKAT
}

\author{
Wahyu Widayat \\ Pusat Teknologi Lingkungan, BPPT, Kawasan Puspiptek, Tangerang Selatan, 15314, Indonesia \\ Email : wdytwahyuw09@gmail.com
}

\begin{abstract}
ABSTRAK
Sumber air minum daerah padat penduduk dan masyarakat pesisir dipenuhi dari air permukaan atau sumur dalam. Air permukaan dipengaruhi oleh pasang air air laut, sehingga hampir sepanjang waktu dalam setahun kualitas airnya payau bahkan asin. Disamping konsentrasi garam yang tinggi, kualitas air sumur dalam juga buruk yaitu mengandung zat organik, besi dan mangan tinggi, hal ini disebabkan oleh struktur tanah dan sanitasi lingkungan yang buruk dari masyarakat nelayan. Penggunaan air hujan sebagai sumber air alternatif dalam pemecahan masalah tersebut, terbatas untuk memenuhi kebutuhan air minum di musim penghujan. Alternatif lain, masyarakat harus mencari dari daerah lain yang jauh dari rumah mereka atau membeli air dengan harga mahal. Untuk memecahkan masalah kritis ini diperlukan penerapan teknologi pengolahan air yang sesuai. Teknologi pengolahan air ini harus menghasilkan air minum yang memenuhi standar teknis dan teknologi yang aplikatif, mudah dan murah dalam operasi dan pemeliharaan karena diharapkan masyarakat di daerah itu dapat mengelola, mengoperasikan dan maintenace. Teknologi osmosa balik untuk mengolah air asin menjadi air minum merupakan salah satu alternatif untuk memenuhi kebutuhan air minum yang memenuhi syarat teknis kesehatan dan hasil pengelolaannya dapat meningkatkan derajad sosial maupun ekonomi masyarakat nelayan.
\end{abstract}

Kata kunci : air minum, air asin, masyarakat pesisir, osmosa balik, padat penduduk

\section{INNOVATION OF DRINKING WATER TECHNOLOGY BASED ON COMMUNITY}

\author{
Wahyu Widayat \\ Center for Environmental Technology, BPPT, Puspiptek Area, South Tangerang, 15314, Indonesia \\ Email : wdytwahyuw09@gmail.com
}

\begin{abstract}
Drinking water sources in densely populated and coastal communities, are coming from surface water and deep wells. Surface water source is affected by tidal; therefore the water is salty or brackish most of the year. Beside the high salt concentration, the water quality is poor which contains organic matter, iron and manganese. These poor qualities are caused by the nature of their soil structure and poor sanitation. Rainy water is one of the alternative sources but limited only in the rainy season. The other alternatives are people look for fresh water which quite distant from the residence or buy fresh water with expensive price. The technology to solve this problem is required to meet water requirements. The water treatment technology shall meet the criteria, such as the product meet the standard, easy for operational and maintenance, and also low cost effective. Reverse osmosis is one of the alternative technologies to treat brackish or salty water into drinking water which fulfill the health regulation standard and can increase of social and economic community of fishermen
\end{abstract}

Keywords : brackish water, coastal communities densely populated, drinking water, reverse osmosis

\section{PENDAHULUAN}

Air merupakan salah satu materi yang tidak dapat dipisahkan dalam kehidupan manusia dengan segala aktivitasnya, sehingga merupakan kebutuhan pokok bagi kehidupan manusia. Apabila kebutuhan akan air tersebut belum tercukupi dapat memberikan dampak yang besar terhadap kerawanan kesehatan maupun sosial.
Di Indonesia pelayanan air bersih sebagai air baku untuk air minum dalam skala besar masih terpusat di daerah perkotaan, dan dikelola oleh Perusahan Daerah Air Minum (PDAM) kota yang bersangkutan. Pelayanan penyediaan air bersih secara nasional masih jauh dari mencukupi dan dapat dikatakan relatif kecil yakni 16,08 \% (Prihatin, 2015). Untuk daerah yang belum mendapatkan pelayanan air bersih dari PAM 
umumnya mereka menggunakan air tanah (sumur), air sungai, air hujan, air sumber (mata air) dan lainnya. Prosentasi banyaknya rumah tangga dan sumber air minum yang digunakan di berbagai daerah di Indonesia sangat bervariasi tergantung dari kondisi geografisnya. Secara nasional yang menggunakan air leding 16,08 \%, air tanah dengan memakai pompa $11,61 \%$, air sumur (perigi) 49,92 \%, mata air (air sumber) $13,92 \%$, air sungai $4,91 \%$, air hujan $2,62 \%$ dan lainnya 0,80 (Sundoro, 2017).

Pada umumnya daerah padat penduduk air tanahnya tidak layak untuk dikonsumsi, karena sudah tercemar oleh air limbah domestik, industri, rumah sakit dan untuk masyarakat padat penduduk di sekitar pesisir tercemar oleh kandungan garam. Di daerah padat penduduk ini, ada beberapa permasalahan mendasar yang sering timbul yakni kulaitas air tanah maupun air sungai yang digunakan masyarakat kurang memenuhi syarat sebagai air minum yang sehat bahkan di beberapa tempat bahkan tidak layak untuk diminum (Sunil, 2008). Air dengan kualitas layak diminum mempunyai standar persyaratan tertentu yakni persyaratan fisis, kimiawi dan bakteriologis, dan syarat tersebut merupakan satu kesatuan, sehingga apabila ada satu saja parameter yang tidak memenuhi syarat maka air tesebut tidak layak untuk diminum. Pemakaian air minum yang tidak memenuhi standar kualitas tersebut dapat menimbulkan gangguan kesehatan, baik secara langsung dan cepat maupun tidak langsung dan secara perlahan.

Air tanah pada umumnya mengandung zat besi (Fe) dan Mangan (Mn) cukup besar dan untuk daerah pesisir mengandung kadar garam tinggi. Adanya kandungan $\mathrm{Fe}$ dan $\mathrm{Mn}$ dalam air ditandai dengan adanya perubahan fisis, yaitu ditunjukkan dengan perubahan warna air menjadi kuning-coklat setelah terjadi oksidasi, yaitu beberapa saat kontak dengan udara (Pan Zhang, 2013). Disamping dapat mengganggu kesehatan juga menimbulkan bau yang kurang enak serta menyebabkan warna kuning pada dinding bak serta bercak - bercak kuning pada pakaian. Oleh karena itu menurut permenkes Nomor 492/Menkes/per/IV/2010 tersebut, kadar (Fe) dalam air minum maksimum yang dibolehkan adalah 0,3 mg/lt, dan kadar Mangan (Mn) dalam air minum yang dibolehkan adalah $0,1 \mathrm{mg} / \mathrm{lt}$.

Permasalahan yang sering timbul saat ini adalah banyak kawasan pemukiman yang telah dibangun di dalam kawasan yang kualitas air tanahnya tidak dapat digunakan sebagai sumber air minum misalnya airnya mengandung zat besi atau mangan dengan konsentrasi yang cukup tinggi atau merupakan kawasan yang air tanahnya payau. Dilain pihak pelayanan air bersih atau suplai air dari PAM setempat belum ada. Akibatnya masyarakat harus memenuhi air untuk kebutuhan minum dengan cara membeli air minum kemasan dengan harga yang sangat mahal yakni sekitar Rp. 12.000,00 sampai Rp, 22.000,00 per 20 liter. Dengan demikian maka kondisi tersebut sangat memberatkan masyakarat khusunya masyarakat miskin (Juniar, 2012)

Dalam rangka mengatasi permasalahan tersebut di atas, Pusat Teknologi Lingkungan, BPP Teknologi, telah mengembangkan paket teknologi untuk mengolah air tanah, air sumur menjadi air yang dapat langsung diminum tanpa dimasak terlebih dahulu. Unit alat tersebut terdiri dari pompa air baku, unit oksidasi, filter pasir, filter mangan zeolit, filter karbon aktif, cartridge filter, osmosa balik dan ultra violet. Unit alat tersebut dapat dirancang dalam bentuk paket yang kompak dan sederhana disesuaikan dengan kondisi sosial ekonomi masyarakat dengan kapasitas olah dapat disesuaikan dengan kebutuhan suatu wilayah yang diinginkan.

\section{BAHAN DAN METODE}

Pelaksanaan kegiatan ini diawali dengan Survei lokasi dan kualitas air yang akan digunakan antara lain air baku, selanjutnya membuat desain proses dan unit pengolahan, pembangunan unit pengolahan air siap minum lengkap dengan bangunan pelindung peralatan, uji coba dilanjutkan dengan paket pelatihan.

\section{a. Pemilihan dan Penentuan Lokasi}

Pemilihan lokasi penempatan unit alat pengolah air siap minum ditentukan tidak terlalu jauh dari pemukiman masyarakat setempat, memuaskan baik ditinjau dari segi teknis maupun estetika (Dwiwinarno,2011).

\section{b. Pemilihan Bahan dan Peralatan}

Bahan dan peralatan yang diperlukan untuk pembangunan unit pengolahan air siap minum diperoleh dengan mudah didapat di pasaran, sehingga dapat memberikan kemudahan dalam pengerjaan pembangunan dan biaya konstruksi dapat ditekan serendah mungkin (Darmawansa, 2009).

\section{c. Perancangan dan Konstruksi}

Perancangan unit alat pengolah air siap minum dirancang berdasarkan jumlah masyarakat yang akan dilayani dan kualitas air baku yang akan diolah, serta sesuai dengan ketersediaan lahan yang ada. Alat pengolah air siap minum tersebut tersebut dirancang dalam bentuk yang kompak agar pemasangan / pembangunan serta operasinya mudah, serta menggunakan energi yang efisien (D. Ariyanti, 2011). 


\section{d. Pengujian Karakteristik Alat}

Unit alat pengolahan air siap minum siap dioperasikan dilakukan pengujian karakteristik alat dan pengujian hasil pengolahan terhadap beberapa parameter sesuai dengan stadar kesehatan.

\section{HASIL DAN PEMBAHASAN}

\subsection{Hasil}

\subsubsection{Penentuan Kapasitas Pengolahan}

Penentuan kapasitas pengolahan dihitung berdasarkan jumlah kebutuhan air minum untuk keperluan rumah tangga dan kegiatan berlayar untuk masyarakat padat penduduk di daerah pesisir. Jumlah rata-rata kapal di daerah padat penduduk pesisir 100 sampai 200 dan setiap 10 hari membutuhkan 10 - 15 galon air minum sehingga rata-rata kebutuhan air minum keperluan berlayar $=300$ galon/hari. Area yang dapat dilayani secara optimal masyarakat pesisir adalah 400 kepala keluarga (KK), dengan ratarata kebutuhan air minum 1 galon air minum per 2 hari per KK maka kebutuhan air minum sebesar 200 galon air/hari. Kebutuhan total air minum ditentukan 500 galon air per hari setara $10.000 \mathrm{l} / \mathrm{hari}$.

\subsubsection{Penentuan Proses Pengolahan}

Pemilihan proses pengolahan air minum ditentukan berdasarkan tingkat kebutuhan, kualitas air hasil pengolahan dan kondisi sosial serta budaya masyarakat. Tingkat kebutuhan air dalam kemasan masyarakat yang akan dilayani sekitar 500 galon air kemasan per hari, sehingga pemilihan proses yang cepat dalam kapasitas besar dengan kualitas yang baik dan memenuhi persyaratan sebagai air minum adalah proses osmosa balik dan distilasi. Investasi dan konsumsi energi untuk proses desalinasi dengan proses distilasi lebih besar dari pada proses osmosa balik (Mogheir, 2015). Masyarakat padat penduduk di sekitar pesisir terbiasa dengan permesinan diesel untuk penggerak kapal yang setara dengan pembangkit listrik genset, sehingga penguasaan teknologi penggunaan genset sebagai sumber tenaga listrik untuk pengolahan air sangat mudah (Soedjono, 2012). Kemudahan penguasaan teknologi, kecepatan produksi, kualitas air hasil pengolahan dan konsumsi energi desalinasi dengan proses osmosa balik lebih mudah diterima oleh masyarakat pesisir dibandingkan dengan distilasi, maka ditentukan proses yang digunakan untuk mengolahan air tanah yang tercemar air asin menjadi air minum adalah menggunakan proses osmosa balik. Berdasarkan hasil analisa kualitas air baku proses osmosa balik ini terbagi dalam 2 unit proses yaitu pengolahan pendahuluan untuk memenuhi standar kualitas air baku yang akan diolah pada unit osmosa balik dan pengolahan lanjut untuk penghilangan garam, diagram alir proses dapat dilihat pada Gambar 10 dan aplikasinya dapat dilihat pada Gambar 11 yang terdapat di dalam Lampiran.

Pada umumnya kualitas air sumur atau air tanah mempunyai karakteristik yang berbeda dengan kualitas air permukaan. Air tanah pada umumnya jernih, namun sering mengandung mineral atau garam yang cukup tinggi, sebagai akibat dari pengaruh batuan dibawah tanah yang dilalui oleh air tanah. Pada air tanah dangkal, kualitas dan kuantitasnya dipengaruhi oleh kondisi lingkungan di permukaanya, dalam hal kuantitas sangat dipengaruhi oleh curah hujan setempat, sementara kualitasnya dipengaruhi oleh kondisi sanitasi disekitarnya.(Sane, 2011).

Proses pengolahan air tanah dengan konsentrasi garam tinggi menjadi air yang siap minum, seperti ditunjukkan pada Gambar 10. Air dari tanah dipompa ke unit aerasi untuk oksidasi menggunakan udara selanjutnya dengan menggunakan pompa semi jet, sambil diinjeksi dengan larutan kaporit atau kalium permanganat dengan konsentrasi disesuaikan dengan kualitas air baku, selanjutnya dialirkan ke saringan pasir, saringan mangan zeolith dan saringan karbon aktif untuk menyaring oksida besi, mangan, logam-logam lainnya, menyerap bau serta warna dan dilanjutkan saringan kontak media kapur untuk menaikkan $\mathrm{pH}$. Setelah melalui saringan tersebut air dialirkan ke filter bag filter ukuran 10 mikron dan dilanjutkan dengan penyaringan menggunakan cartrige filter ukuran 1 mikron untuk menghilangkan sisa partikel padatan yang ada di dalam air sehingga air menjadi benarbenar jernih. untuk menjamin air produk layak dikonsumsi, bebas dari bakteri dan mikroorganisme yang merugikan, air dialirkan ke sistem osmosa balik dilanjutkan dengan sterilisasi ultra violet

\subsubsection{Pengolahan Pendahuluan}

Berdasarkan data kualitas air baku mengandung besi, mangan dan kandungan garam tinggi seperti yang disajikan dalam Tabel 1 , diperlukan pengolahan pendahuluan atau yang disebut dengan pretreatment terdiri dari proses oksidasi dan filtrasi. Proses oksidasi dua tahap yaitu oksidasi menggunakan udara dan dilanjutkan oksidasi menggunakan bahan oksidator kalium permanganat $\left(\mathrm{KMnO}_{4}\right)$ atau kaporit sedangkan proses filtrasi menggunakan saringan pasir cepat, saringan mangan zeolit, saringan karbon aktif dan cartridge filter (Ariyanti, 2009)

Kecepatan aliran dan debit air baku merupakan variabel penting dalam proses desalinasi dengan membran, yaitu untuk 
melakukan penggelontoran materi secara efektif dengan memanfaatkan kecepatan aliran dan debit air buangan (reject) atau yang disebut dengan self cleaning service. Perbandingan kecepatan aliran maupun debit air hasil pengolahan dengan buangan minimal 1:1 untuk mendapatkan self cleaning service (Pinem, 2010). Rancangan osmosa balik untuk mendapatkan air minum 10.000 liter/hari, diperlukan sistem pengolahan pendahuluan dengan kapasitas dua sampai tiga kali lipat kapasitas unit pengolahan lanjutan, yaitu sebesar $20.000-30.000$ liter per hari.

\subsubsection{Oksidasi Menggunakan Udara dan $\mathrm{KMnO}_{4}$}

Kontak air dengan udara bertujuan untuk mengoksidasi kandungan besi, magan dan logam - logam lainnya serta menghilangkan bau. Oksidasi kontak dengan udara membantu mengurangi pemakaian bahan kimia untuk oksidasi serta mengurangi beban saringan karbon aktif dalam menyerap bau. $\mathrm{pH}$ air baku dan waktu kontak mempengaruhi efisiensi proses oksidasi menggunakan udara, semakin lama waktu kontak dan $\mathrm{pH}$ semakin tinggi efisiensi oksidasi menggunakan udara semakin baik (Kuppusamy, 2011).

Oksidasi menggunakan $\mathrm{KMnO}_{4}$ bertujuan untuk melanjutkan proses oksidasi besi dan mangan atau logam - logam valensi dua lainnya yang tidak teroksidasi pada kontak air dengan udara. Pembubuhan $\mathrm{KMnO}_{4}$ selain berfungsi sebagai oksidator, selain itu juga sebagai bahan regenerasi atau aktivasi media filter mangan zeolit (manganese greensand). Persamaan reaksi oksidasi besi dan mangan oleh kalium permanganate adalah sebagai berikut (Hammer, 2011).

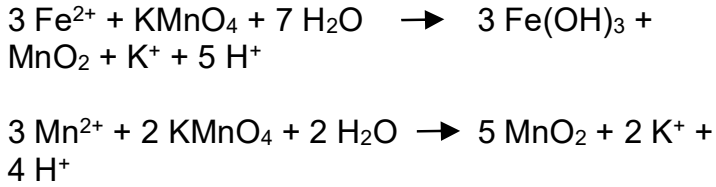
$4 \mathrm{H}^{+}$

Secara stokhiometri, untuk mengoksidasi 1 $\mathrm{mg} / \mathrm{l}$ besi diperlukan 0,94 $\mathrm{mg} / \mathrm{l}$ kalium permanganat dan untuk $1 \mathrm{mg} / \mathrm{l}$ mangan diperlukan 1,92 $\mathrm{mg} / \mathrm{l}$ kalium permanganate (Hammer, 2011). Aplikasi di lapangan, kebutuhan kalium permanganat ternyata lebih sedikit dari kebutuhan yang dihitung berdasarkan stokhiometri, hal ini disebabkan karena terbentuknya mangan dioksida yang berlebihan yang dapat berfungsi juga sebagai oksidator dan reaksi berlanjut sebagai berikut (Hammer, 2011):

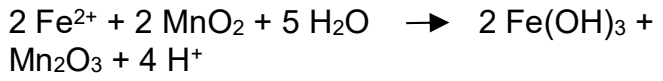

$$
3 \mathrm{Mn}^{2+}+\mathrm{MnO}_{2}+4 \mathrm{H}_{2} \mathrm{O} \rightarrow 2 \mathrm{Mn}_{2} \mathrm{O}_{3}+8 \mathrm{H}^{+}
$$

Pompa dosing terkecil dengan kapasitas maksimun 4,7 liter per jam cukup untuk menginjeksi $\mathrm{KMnO}_{4}$ dan laju injeksi dapat diatur dengan cara mengatur jumlah ketukan atau langkah sekala pompa dosing.

\subsubsection{Saringan Pasir Cepat}

Dimensi saringan pasir cepat untuk mengolah air baku 30.000 liter berdiameter 12 inch tinggi $150 \mathrm{~cm}$. Padatan yang terdapat di dalam air baku, oksida besi, oksida mangan maupun oksida logam lainnya yang terbentuk dari proses oksidasi tertahan di saringan pasir cepat dan dapat dibuang dengan proses pembilasan seperti pada Gambar 1. Susunan media saringan pasir cepat dapat dilihat pada Gambar 1, yaitu dari bawah ke atas terdiri dari kerikil kasar dengan ketebalan 5-10 cm, kerikil halus $5-10 \mathrm{~cm}$, pasir kuarsa/silika kasar $30 \mathrm{~cm}$ dan pasir silika halus $50 \mathrm{~cm}$.

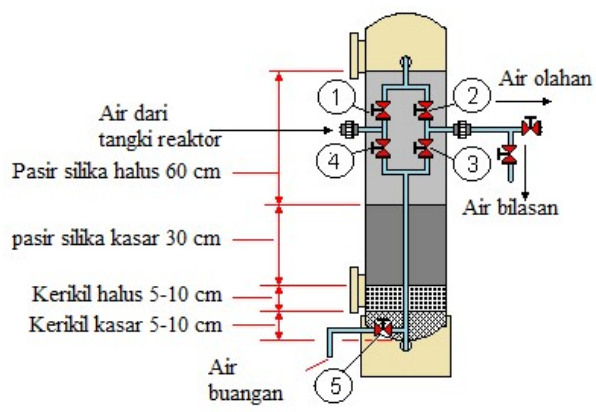

Gambar 1. Susunan media saringan pasir cepat
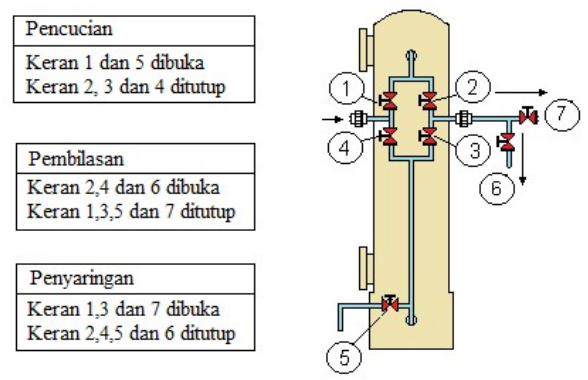

Gambar 2. Pengoperasian saringan pasir cepat

\subsubsection{Saringan Mangan Zeolit}

Media mangan Zeolit ditempatkan dalam saringan dengan diameter 12 inch dan tinggi 150 $\mathrm{cm}$ dengan susunan media dari bawah ke atas batu kerikil kasar dengan ketebalan 5-10 cm, kerikil halus $5-10 \mathrm{~cm}$, pasir silika kasar $10 \mathrm{~cm}$, pasir silika halus $20 \mathrm{~cm}$ dan mangan zeolit $50 \mathrm{~cm}$ seperti ditunjukkan dalam Gambar 3 dan cara pengoperasiannya dapat dilihat pada Gambar 4. Mangan zeolit berfungsi sebagai katalis dan pada waktu yang bersamaan besi dan mangan yang 
terkandung di dalam air baku teroksidasi menjadi bentuk ferri oksida dan mangan dioksida yang tidak larut dalam air, dengan reaksi sebagai berikut (Hammer, 2011):

$\mathrm{K}_{2} \mathrm{Z} \cdot \mathrm{MnO} \cdot \mathrm{Mn}_{2} \mathrm{O}_{7}+4 \mathrm{Fe}\left(\mathrm{HCO}_{3}\right)_{2} \rightarrow \mathrm{K}_{2} \mathrm{Z}+3 \mathrm{MnO}_{2}$ $+2 \mathrm{Fe}_{2} \mathrm{O}_{3}+8 \mathrm{CO}_{2}+4 \mathrm{H}_{2} \mathrm{O}$

$\mathrm{K}_{2} \mathrm{Z} \cdot \mathrm{MnO} \cdot \mathrm{Mn}_{2} \mathrm{O}_{7}+2 \mathrm{Mn}\left(\mathrm{HCO}_{3}\right)_{2} \rightarrow \mathrm{K}_{2} \mathrm{Z}+5 \mathrm{MnO}_{2}$ $+4 \mathrm{CO}_{2}+2 \mathrm{H}_{2} \mathrm{O}$

Reaksi penghilangan besi dan mangan dengan media mangan zeoilte merupakan reaksi dari $\mathrm{Fe}^{2+}$ dan $\mathrm{Mn}^{2+}$ dengan oksida mangan tinggi (higher mangan oxide). Filtrat yang terjadi mengandung ferri-oksida dan mangan-dioksida yang tidak larut dalam air dapat dipisahkan dengan pengendapan dan penyaringan. Selama proses berlangsung kemampunan reaksinya semakin lama semakin berkurang dan akhirnya menjadi jenuh. Untuk regenerasinya dapat dilakukan dengan menambahkan larutan $\mathrm{KMnO}_{4}$ ke dalam mangan zeolite yang telah jenuh tersebut sehingga akan terbentuk lagi mangan zeolite $\left(\mathrm{K}_{2} \mathrm{Z} . \mathrm{MnO} . \mathrm{Mn}_{2} \mathrm{O}_{7}\right)$ (Darmawansa, 2009).

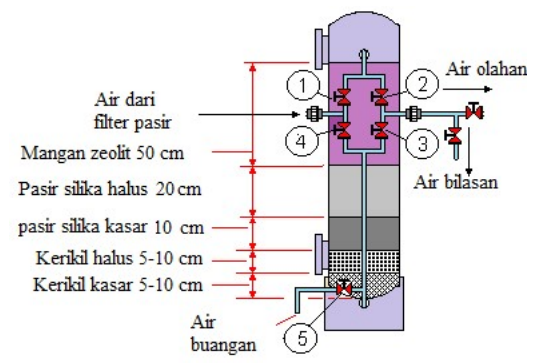

Gambar 3. Susunan media saringan mangan zeolit
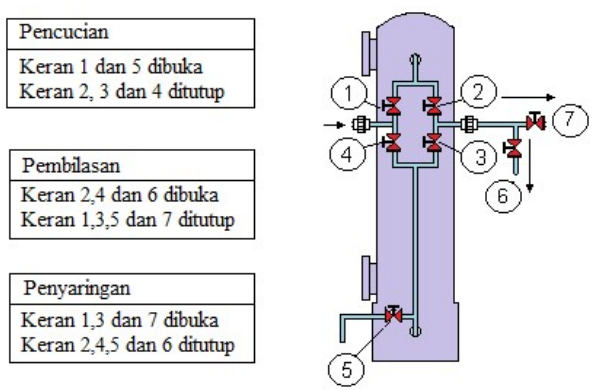

Gambar 4. Pengoperasian saringan mangan zeolit

\subsubsection{Saringan Karbon Aktif}

Media karbon aktif juga ditempatkan di dalam saringan dengan diameter 12" dan tinggi $150 \mathrm{~cm}$ dengan susunan ketebalan dari bawah ke atas yaitu kerikil kasar $5-10 \mathrm{~cm}$, kerikil halus $5-10 \mathrm{~cm}$, pasir silica kasar $10 \mathrm{~cm}$, pasir silica halus $10 \mathrm{~cm}$ dan karbon akti $60 \mathrm{~cm}$. Skema susunan media dan pengoperasian filter karbon aktif seperti ditunjukkan pada Gambar 5. Saringan karbon aktif berfungsi untuk menghilangkan polutan mikro misalnya zat organik, deterjen, bau, senyawa fenol serta untuk menyerap logam berat dan warna (Pabby, 2009). Apabila seluruh permukaan karbon aktif sudah mengalami kejenuhan, maka efisiensi proses penyerapan akan berkurang dan akhirnya berhenti, dan pada saat ini karbon aktif harus diganti dengan karbon aktif yang baru. Cara pengoperasian saringan karbon aktif dapat dilihat pada Gambar 6.

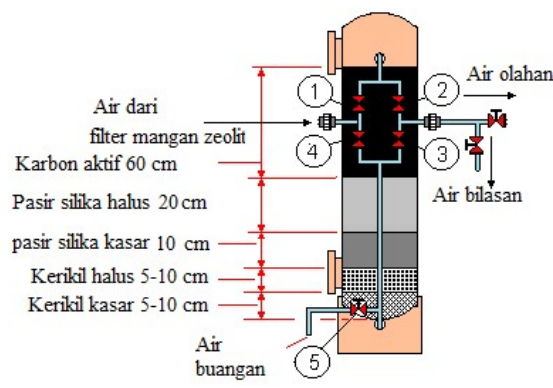

Gambar 5. Susunan media saringan karbon aktif
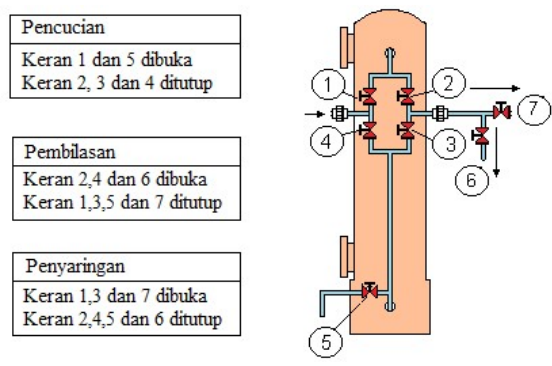

Gambar 6. Pengoperasian saringan karbon aktif

\subsubsection{Saringan Adjuster pH}

Skema susunan media dan pengoperasian filter Adjuster pH seperti ditunjukkan pada Gambar 7 dan cara pengoperasiannya dapat dilihat pada Gambar 8.

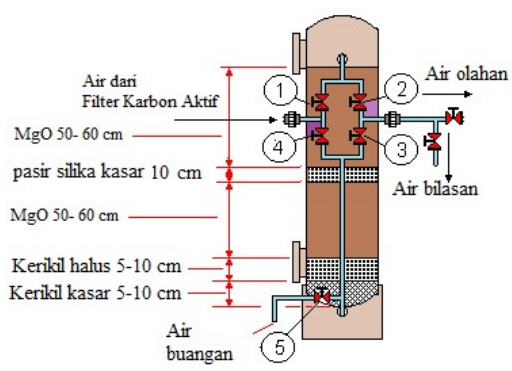

Gambar 7. Susunan media saringan adjuster $\mathrm{pH}$ 

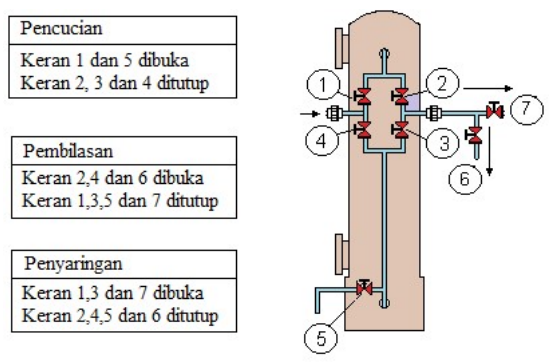

Gambar 8. Pengoperasian saringan adjuster $\mathrm{pH}$

Media Adjuster pH menggunakan Magnesium oksida yang bekerja dengan cara menetralisasi kandungan karbon dioksida di dalam air, sehingga memperbaiki kondisi asam pada air baku maupun air hasil olahan. Perubahan $\mathrm{pH}$ dan pemakaian media tergantung dari kondisi air baku. Karena media $\mathrm{MgO}$ (Magnesium Oksida) akan terlarut secara perlahan, maka media ini harus ditambahkan secara teratur $4-6$ bulan sekali. Dengan berat yang sama, MgO dapat menetralkan keasaman air jauh lebih optimal dibandingkan media lain seperti Kalsium karbonat (Haiyan, 2016). MgO sebagai adjuster $\mathrm{pH}$ ditempatkan di dalam saringan dengan diameter 12 " dan tinggi $150 \mathrm{~cm}$ dengan ketebalan $50-60 \mathrm{~cm}$ dan dalam penggunan melebihi $60 \mathrm{~cm}$ disusun dalam 2 susunan yang dibatasi dengan pasir silika untuk menghindari pemadatan dan mempermudah melakukan pencucian balik. Susunan media dari bawah ke atas yaitu kerikil kasar $5-10 \mathrm{~cm}$, kerikil halus $5-10 \mathrm{~cm}, \mathrm{MgO} 50-60 \mathrm{~cm}$, pasir silika kasar $10 \mathrm{~cm}, \mathrm{MgO} 50-60 \mathrm{~cm}$.

\subsubsection{Cartridge Filter}

Unit proses dilengkapi dengan cartridge filter dengan ukuran $1 \mu \mathrm{m}$, sehingga secara keseluruhan produk air dari unit pengolahan pendahuluan ini diharapkan mempunyai kualitas yang dipersyaratkan unit osmosa balik seperti Tabel berikut.

Tabel 1. Standar kualitas air baku untuk air umpan unit osmosa balik (Baker, 2012)

\begin{tabular}{clcr}
\hline No & Parameter & Satuan & Air Baku \\
\hline 1 & Warna & Pt.Co & 100 \\
& & Scale & \\
2 & Bau & - & Relatif \\
3 & Kekeruhan & $\mathrm{NTU}$ & 20 \\
4 & Besi & $\mathrm{mg} /$ liter & 2,0 \\
5 & Mangan & $\mathrm{mg} /$ liter & 1,3 \\
6 & Khlorida & $\mathrm{mg} /$ liter & 4.000 \\
7 & Bahan & $\mathrm{mg} /$ liter & 40 \\
& Organik & & \\
8 & TDS & $\mathrm{mg} /$ liter & $<35.000$ \\
\hline
\end{tabular}

Tabel 1 menunjukkan kekeruhan $<5$ NTU, $\mathrm{Fe}, \mathrm{Mn}<0,1 \mathrm{ppm}$ dan Chlorida juga $<0,01 \mathrm{ppm}$. Unit pengolahan pendahuluan di atas belum dapat menghilangkan kadar garam, sehingga diperlukan pengolahan lanjutan untuk penghilangan garamnya (desalinasi)

\subsubsection{Pengolahan Lanjutan}

Pengolahan lanjutan yaitu proses penyaringan dengan menggunakan membran untuk menghasilkan air siap minum, air tanah yang mengandung besi, mangan dan garam yang telah diolah dan telah memenuhi persyaratan seperti Tabel 1, dipompa dengan tekanan tinggi ke dalam 4 modul membran osmosa balik dengan dimesnsi tiap modul diameter 4" panjang 40". Efisiensi penghilangan garam dengan proses osmosa balik ini mencapai 99,5\% (Baker, 2012). Modul membran osmosa balik mempunyai dua buah pipa keluaran, yakni pipa keluaran untuk air tawar sebagai produk dan pipa keluaran untuk air garam yang telah dipekatkan sebagai buangan. Di dalam membran osmosa balik terjadi proses penyaringan dengan skala molekul, yaitu partikel yang molekulnya lebih besar dari pada molekul air, misalnya molekul garam dan lainnya, akan terpisah dan akan ikut ke dalam air buangan (Sight, 2014).

Penyaringan skala molekul menggunakan osmosa balik ini selain memperhatikan kualitas air baku seperti yang dipersyaratkan di dalam Tabel 1 juga perlu diperhatikan kandungan materi yang memicu pengerakan, bahan-bahan organik, sehingga perlu diinjeksi 3 jenis bahan kimia, yaitu anti scalant (anti pengerakan), anti biofouling (anti penyumbatan karena unsur biologis) dan bahan pengawet yang berfungsi untuk mengawetkan membran. Bahan - bahan yang diinjeksikan tidak akan terikut di dalam produk air minum, karena tersaring dan keluar bersama dengan air buangan. Pengerakan yang menutupi pori membran osmosa balik diindikasikan dengan penurunan debit air hasil olahan dan diikuti dengan kenaikan tekanan operasi. Kondisi seperti ini diperlukan pencucian membran menggunakan bahan kimia dengan kombinasi asam dan basa kuat (Widiasa, 2008)

\subsection{Pembahasan}

Sistem osmosa merupakan bagian vital kegiatan kapal laut untuk memenuhi kebutuhan air bersih sebagai pendukung utama pelayaran dalam jangka waktu lama yang tidak memungkinkan membawa air tawar sesuai dengan kebutuhan pelayaran walaupun dengan biaya investasi, pengoperasian dan perawatan yang mahal (Ashlynn, 2010). Seiring perkembangan teknologi membran yang semakin pesat, terutama pada elemen dan sistem 
konfigurasi yang digunakan di dalam unit membran osmosa balik, saat ini sangat memungkinkan untuk diaplikasikan dalam sekala rumah tangga maupun komunal, karena kontruksi membran semakin tipis namun kuat, selektivitas terhadap materi semakin tinggi dan energi osmosa balik yang digunakan semakin rendah (Ariyanti, 2009). Kemudahan proses dan konsumsi energi osmosa balik saat ini menjadi pilihan di berbagai kegiatan untuk memenuhi kebutuhan air minum. Aplikasi membran osmosa balik sangat fleksibel dalam peningkatan kapasitas pengolahan, karena menggunakan sistem modul yang kapasitas pengolahannya berbanding lurus dengan dimensi membrane.

Membran osmosa balik merupakan media filter yang memiliki pori paling kecil dibandingkan filter-filter yang lain yaitu 0.0001 mikron, sehingga mampu memisahkan komponenkomponen yang tidak diinginkan seperti komponen organik, non organik, bakteri, virus, partikulat, serta ion atau garam terlarut. Membran semipermeabel di dalam aplikasi kontruksi osmosa balik berupa lapisan tipis polimer pada penyangga berpori (fabric support). Membran untuk kebutuhan komersial harus memiliki sifat permeabilitas yang tinggi terhadap air, tahan terhadap variasi $\mathrm{pH}$ dan suhu. Selain itu, membrane juga harus memiliki derajat semipermeabilitas yang tinggi dalam arti laju transportasi air melewati membran harus jauh lebih tinggi dibandingkan laju transportasi ion-ion yang terlarut dalam umpan. Laju transportasi air yang lebih tinggi dibandingkan dengan ion-ion yang tertahan di permukaan membran dimanfaatkan sebagai penggelontoran materi atau pengotor yang tertahan di permukaan membran sehingga pori-pori membrane dalam keadaan selalu bersih dari pengotor (Sight, 2014). Kestabilan dari sifat sifat tersebut dalam periode waktu dan kondisi tertentu akan mengalami penurunan sehingga sangat diperlukan pengolahan pendahuluan yang tersebut di atas dengan tepat untuk mendapatkan hasil pengolahan baik kualitas mapun kuantitas yang setabil. Sesuai dengan standar umur pakai produk membran apabila dioperasikan dengan air baku sesuai yang dipersyaratkan pada Tabel 1, membran osmosa balik dapat dipakai sampai 2-4 tahun. Penerapan proses pendahuluan di dalam sistem osmosa balik seperti rancangan proses di atas mampu memperpanjang umur pakai membran osmosa balik sampai 5 tahun.

Batasan pada teknis pengoperasiannya juga sangat penting untuk diperhatikan yaitu tekanan tidak melebihi dari 60 bar sehingga dalam aplikasi sistem osmosa balik dilengkapi dengan pengukur tekanan (pressure gauge) dan otomatisasi pemutus tekanan serta pemilihan pompa tekanan tinggi yang tidak melebihi 60 bar. Laju alir akan meningkat seiring peningkatan tekanan, namun tekanan yang besar melebihi batas toleransi dapat merusak atau merobek membran sehingga komponen yang semula akan dipisahkan dari air akan terikut sebagai produk. Di dalam kondisi tertentu seperti pengambilan air baku langsung dari air laut atau pengaruh pasang surut air laut perlu dilengkapi pula beberapa alat tambahan yang digunakan untuk mempertahankan kinerja membran osmosa balik yaitu unit autoflush yang berfungsi untuk meminimalisasi fenomena pengerakan (fouling dan scaling). Fouling merupakan perubahan morfologi membran secara irreversibel yang disebabkan oleh interaksi fisik dan/atau kimia spesifik antara membran dengan berbagai komponen yang ada dalam cairan umpan, antara lain koloid, partikel halus, minyak, mikroorganisme, oksida logam, dan silika. Sedangkan scaling adalah presipitasi kristal garam di permukaan membran seperti $\mathrm{CaCO}_{3}$, CaSO4, BaSO4, $\mathrm{SrSO}_{4}, \mathrm{CaF}_{2}$, dan $\mathrm{Mg}(\mathrm{OH})_{2}$ (Diawara, 2011). Instalasi osmosa balik skala komunal atau besar, minimalisasi fouling dan scaling umumnya menggunakan senyawa penghambat kerak atau sering disebut sebagai antiscalant atau scale intibitor. Dominasi kerak yang menempel permukaan membran terhadap luas permukaan porositas membran mengakibatkan tekanan operasional meningkat diiringi dengan penurunan debit produksi air minum (Etikasari, 2009). Pengembalian kondisi operasional normal membutuhkan perawatan dengan melakukan pencucian membran atau yang disebut dengan cleaning membrane yang melibatkan proses pelarutan kerak menggunakan asam kuat dan basa kuat dan pembilasan dengan menggunakan bahan penggelantang seperti kaporit. Pengolahan pendahuluan yang lengkap seperti yang telah dirancang dan diaplikasikan di atas mampu memperpanjang interval cleaning membran atau memberikan pilihan tindakan yang meniadakan proses cleaning dengan keuntungan aplikasi pengolahan pendahuluan yang tepat sehingga mampu menutup investasi penggantian membran baru untuk mengembalikan efisiensi proses osmosa balik seperti semula.

Biaya yang dibutuhkan dalam instalasi maupun pengoperasian sistem osmosa balik skala komunal sangat bervariasi. Sampai saat ini belum ada metode analisa ekonomi baku yang ditetapkan untuk menganalisa biaya yang dibutuhkan karena variabel yang berpengaruh sangat bervariasi. Pembahasan nilai ekonomi pengelolaan peralatan ini dikemukakan dengan suatu metode analisa ekonomi sederhana yang dapat digunakan untuk menghitung biaya produksi/kemasan galon produk air minum yang 
dihasilkan oleh sistem osmosa balik skala komunal seperti yang terlihat pada gambar 10 .

Analisa kelayakan secara ekonomi terdiri dari biaya instalasi dan operasional yang meliputi biaya pengadaan bangunan pelindung, pembelian lahan dan peralatan. Pengadaan peralatan meliputi pembelian dan pemasangan unit pengolahan pendahuluan, pengolahan lanjutan dan power atau tenaga listrik. Biaya operasional merupakan biaya yang diperlukan setelah sistem osmosa balik terpasang dan siap dioperasikan untuk memproduksi air minum. Biaya operasional meliputi pembelian bahan bakar untuk keperluan generator set, pembelian bahan kimia untuk proses oksidasi, perawatan membran dengan penambahan anti scalant, biofoaling dan pengawetan membran, biaya pembelian dan penggantian media filter, pembelian lampu ultraviolet, pembayaran tenaga kerja, pengemasan dan pembiayaan perawatan.

Untuk membangun satu unit instalasi pengolahan tanah yang tercemar air asin dengan sistem osmosa balik kapasitas 10.000 liter/hari atau 500 botol galon air minum per hari ini diperlukan biaya investasi sebesar Rp. 500.000.000,00, tidak termasuk lahan dan bangunan pelindung. Biaya operasional dan pemeliharaan alat termasuk honor pegawai setiap bulannya seperti terlihat pada Tabel 2 . adalah sebesar Rp.30.465.000,00. Biaya produksi air perliternya adalah Rp.102,00 dan apabila air olahan tersebut dijual dengan sistem kemasan botol galon, maka biaya total produksi air perbotol galonnya adalah Rp. 2.050,00. Kebutuhan riil untuk kebutuhan pelayaran dan penduduk sekitar pangkalan pendaratan ikan sebesar 375 galon, dari Tabel 3 analisa pendapatan dan keuntungan hasil penjualan air, terlihat bahwa apabila air tersebut dijual dengan harga Rp. Rp. 5.000,00/botol galon (harga pasaran air kemasan botol galon komersil antara Rp. 8.000,00-12.000,00) dan dengan penjualan $75 \%$ air minum dalam kemasan galon 375 botol galon per hari atau 11.250 botol galon/per bulan, maka diperoleh pendapatan bersih setiap bulan sebesar Rp. 33.187.500,00. Sisa produksi didistribusikan ke desa terdekat untuk keperluan rumah tangga, dengan demikian diperkirakan dengan penjualan $100 \%$ investasi alat kembali pada tahun pertama tanpa memperhitungkan lahan dan bangunan pelindung. Sekenario penjualan dengan berbagai variasi harga, pendapatan dan keuntungan hasil penjualan air minum secara lengkap dapat dilihat pada Tabel 3.

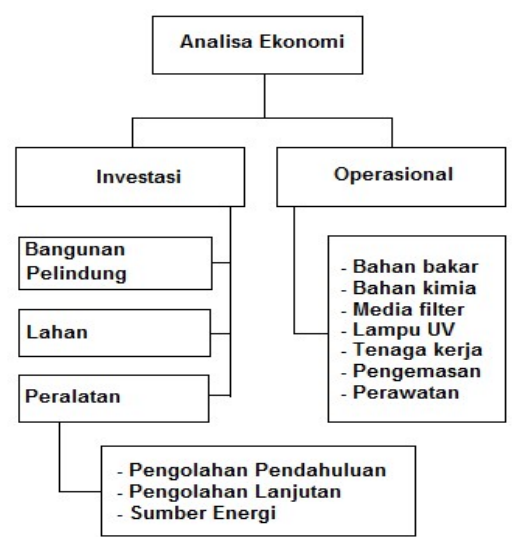

Gambar 9. Struktur analisa ekonomi

\section{Kesimpulan}

Penerapan sistem osmosa balik secara teknis maupun ekonomis lebih unggul dibandingkan dengan metode pemurnian air yang lain. Selain itu hasil perhitungan dan analisa ekonomi menununjukkan bahwa pada instalasi sistem osmosa balik kapasitas air minum dalam kemasan 500 galon/hari membutuhkan biaya Rp. 2.050,00 untuk mengolah air asin dengan kandungan TDS (Total Disolved Solid) 22.000 ppm menjadi air siap minum dengan TDS 50 ppm per botol galon air minum yang dihasilkan.

Aplikasi teknologi pengolahan air tanah yang mengandung besi, mangan dan garam menjadi air siap minum dengan sistem osmosa balik yang diterapkan di daerah pesisir padat penduduk mampu memproduksi air siap minum $10 \mathrm{~m}^{3}$ per hari (500 botol galon air minum/hari). Proses pengolahan dibagi menjadi 2 (dua) bagian utama, yaitu unit pengolahan pendahuluan (pretreatment) dan unit pengolahan lanjutan (treatment). Energi penggerak proses disuplai dari generator set dengan kapasitas 10$15 \mathrm{KVA}, 3$ phase, $380 \mathrm{~V}$, tergantung konsentrasi garam (TDS=Total Disolved Solid).

Manfaat secara langsung aplikasi teknologi pengolahan air tanah yang berasa payau sampai asin dengan sistem osmosa balik terhadap masyarakat setempat adalah memperoleh air minum yang sehat dan memenuhi persyaratan sebagai air minum dengan harga yang jauh lebih murah dari pada air minum dalam kemasan (air dalam kemasan yang dijual secara komersil). Air hasil pengolahan ini langsung dapat diminum tanpa perlu dimasak terlebih dahulu, dengan biaya pengolahan per liter air minum dari air baku air asin adalah Rp. 102,00 dan dalam kemasan gallon Rp. 2.050,00 dimana air minum dalam kemasan saat ini mencapai Rp. 8.000-12.000,00 per botol galon.

Manfaat secara tidak langsung penerapan aplikasi teknologi pengolahan tanah yang tercemar air asin menggunakan sistem osmosa 
balik ini adalah merupakan unit percontohan penerapan teknologi tinggi yang dikemas sangat sederhana sehingga masyarakat dapat mengoperasikan dengan logika sederhana dan mudah diterapkan pada daerah lain.

Manfaat secara umum adalah adanya peningkatan taraf kehidupan dan kesejahteraan masyarakat dengan adanya pendapatan hasil pengelolaan instalasi pengolahan asin menjadi air air minum dan merubah budaya masyarakat sekitar dengan mengkonsumsi air yang sehat dan bersih berarti masyarakat juga terhindar dari kemungkinan menderita sakit yang diakibatkan karena mengkonsumsi air minum yang tidak memenuhi persyaratan sebagai air minum seperti muntaber, disentri atau thypus.

\section{Daftar Pustaka}

1. Ariyanti, D. (2009). Studi Metode Autoflush: Pengendalian Scaling pada Sistem Membran Reverse Osmosis Sekala Rumah Tangga. Universitas Diponegoro, Semarang

2. Ashlynn. (2010). Desalination and Long-Houl Water Transfer as a Water Supply for Dallas, Texas: a Case Study of the Energy-Water Nexus in Texas. Texas Water Journal, volume 1. Number 1. pp 33-41.

3. Baker, R.W. (2012). Membrane Technology \& Aplications. $3^{\text {nd }}$ Edition. John Wiley \& Sons, Chichester.

4. D. Ariyanti, I N. Widiasa. (2011) Aplikasi Teknologi Reverse Osmosis Untuk Pemurnian Air Skala Rumah Tangga. Teknik - Vol. 32 No.3, ISSN 0852-1697

5. Darmawansa. Wahyuni, N., Jati, D.R. 2009. Desalinasi Air Payau Dengan Media Adsorben Zeolit Di Daerah Pesisir Pantai Kecamatan Sungai Kunyit Kabupaten Mempawah. Universitas Tanjungpura, Pontianak.

6. Dwiwinarno, T., Eni A. (2011). Studi Kelayakan Bisnis Air Minum Dalam Kemasan Pdam Kabupaten Kulonprogo. Jurnal Bisnis dan Ekonomi, 2(2), 124 - 135.

7. Diawara, C.K., Saidou, N.D., Mouhamadou, A.D., Michel, F., \& Andre, D. (2011). Performance of Nanofiltration (NF) and Low Pressure Reverse Osmosis (LPRO) Membranes in the Removal of Flourine and Salinity from Brackish Drinking Water. Journal of Water Resources and Protection. 3(12).

8. Etikasari , Yusuf and Tuhu Agung , Rachmanto and Rudy, Laksmono W. (2009) Pengaruh Tekanan Reverse Osmosis Pada Pengolahan Air Payau Menjadi Air Bersih. Envirotek : Jurnal IImiah Teknik Lingkungan, 2 (1). pp. 78-87. ISSN 2085-501-X

9. Haiyan Hu, Lin Zhou \& Qingguo Chen. (2016). Application of Carbon Dioxide and
Polyacrylamide in Extracting Magnesium from Brine by Precipitation Method. Journal of Geoscience and Environment Protection, 4, 194-200.

10. Hammer, M. J. (2011). Water And Waste water Technology . $7^{\text {ed }}$. John Wiley And Sons, New York

11.Juniar A., (2017). Studi Kelayakan Pendirian Pabrik Air Minum Dalam Kemasan Pdam Kabupaten Hulu sungai Utara Ditinjau Dari Aspek Keuangan. Jurnal Manajemen dan Akutansi.11(1). 39-45.

12.Kuppusamy, R., \& Shreedevi, D. K. (2011). Studies on Feasibility of Reverse Osmosis (Membrane) Technology for Treatment of Tannery Wastewater. Journal of Environmental Protection, 2, 37-46

13. Mogheir, Y., Nasser A. (2015). Optimal Management of Brine from Seawater Desalination Plants in Gaza Strip: Deir AL Balah STLV Plant as Case Study. Journal of Environmental Protection, 6, 599-608

14.Pabby, A. K., Rizvi, S. S. H., dan Sastre, A.M.. 2009. Membrane Separations Chemical, Pharmaceutical, Food, and Biotechnological Applications. New York : CRC Press.

15.Pan Zhang , Jingtao Hu , Wei Li \& Houbo Qi. (2013). Research Progress of Brackish Water Desalination by Reverse Osmosis. Journal of Water Resource and Protection, 5, 304-309

16. Permenkes Nomor. 492 / Permenkes / Per / IV / 2010. Persyaratan Kualitas Air Minum

17.Pinem, J.A. (2010). Perlakuan pencucian Membran Reverse Osmosis Terhadap Penurunan Fouling Membran. Jurnal Sains dan Teknologi. Universitas Riau.

18.Prihatin, R.B., Anih S.R., Sri N. Q., Teddy P.S., Winurini U.S., dan Prayitno. Penyediaan Air Bersih di Indonesia: Peran Pemerintah, Pemerintah Daerah, Swasta, dan Masyarakat.ISBN: $\quad$ 978-602-1247-53-2, Cetakan Pertama, Pusat Pengkajian Pengolahan Data dan Informasi (P3DI) Sekretariat Jenderal DPR RI, Jakarta Pusat, 2015

19.Sane, M. G.,2 and M Guddad. (2011). Reverse Osmosis and Membrane Distillation for Desalination of Groundwater. International Scholarly Research Network ISRN Materials Science, 11(9), 523-540

20.Singh, R. (2014). Membrane Technology and Engineering for water Purification: Aplication, System, Design and Operation, 2 ${ }^{\text {nd }} \mathrm{Ed}$, Butterworth-Heinemann.

21.Soedjono, E.S., Dewi, L.K, Azfah, R.A.. 2012. Rancang Bangun Alat Pemurni Air Payau Sederhana Dengan Membran Reverse Osmosis Untuk Memenuhi Kebutuhan Air Minum Masyarakat Miskin Daerah Pesisir. 
Institut Teknologi Sepuluh November, Surabaya.

22.Sundoro, M., (2017). Seminar Nasional KK RALC: Pengelolaan Air Bersih dan Sanitasi Menuju Akses Universal Tahun 2019. Fakultas Teknik Sipil dan Lingkungan, ITB

23.Sunil J. Wimalawansa, S.J. (2008). Purification of Contaminated Water with Reverse Osmosis: Effective Solution of Providing Clean Water for Human Needs in Developing Countries . International Journal of Emerging Technology and Advanced Engineering, 3(12), 375-411.

24. Widiasa, I.N., Wenten, I.G. (2008). Studi

Efektivitas Pencucian Membran Reverse

osmosis Instalasi Air Minum Rumah Tangga.

Prosiding Seminar Nasional Lustrum Teknik

Lingkungan FTSP-ITS, 1 - 2 Oktober. 


\section{LAMPIRAN}

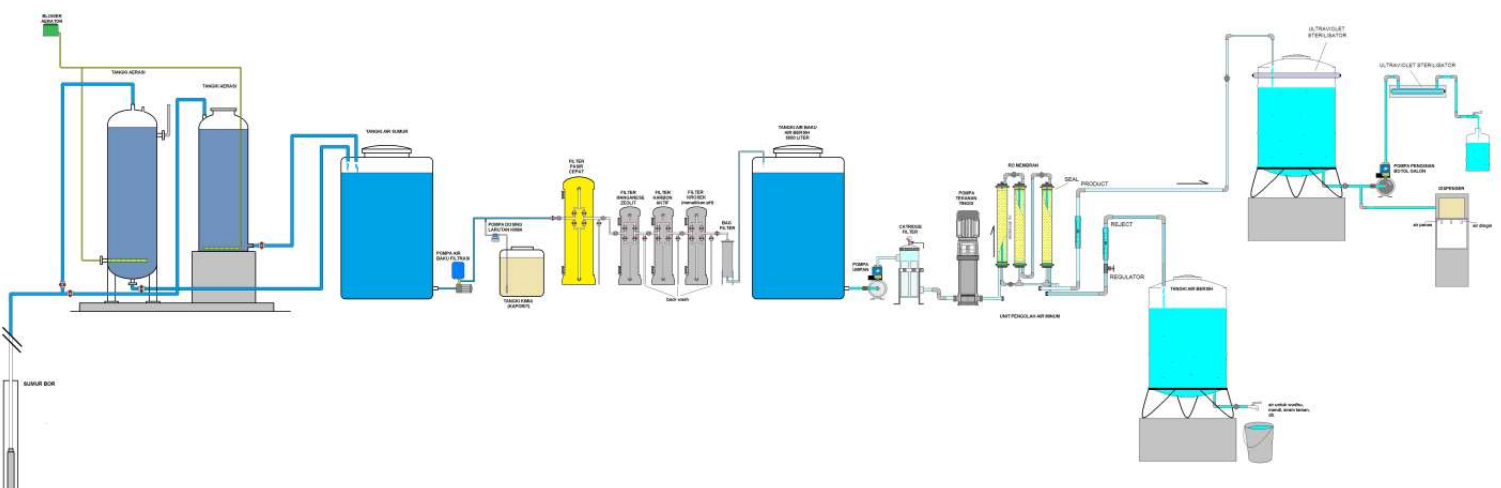

Gambar 10. Proses pengolahan air tanah menjadi air siap minum dengan proses osmosa balik
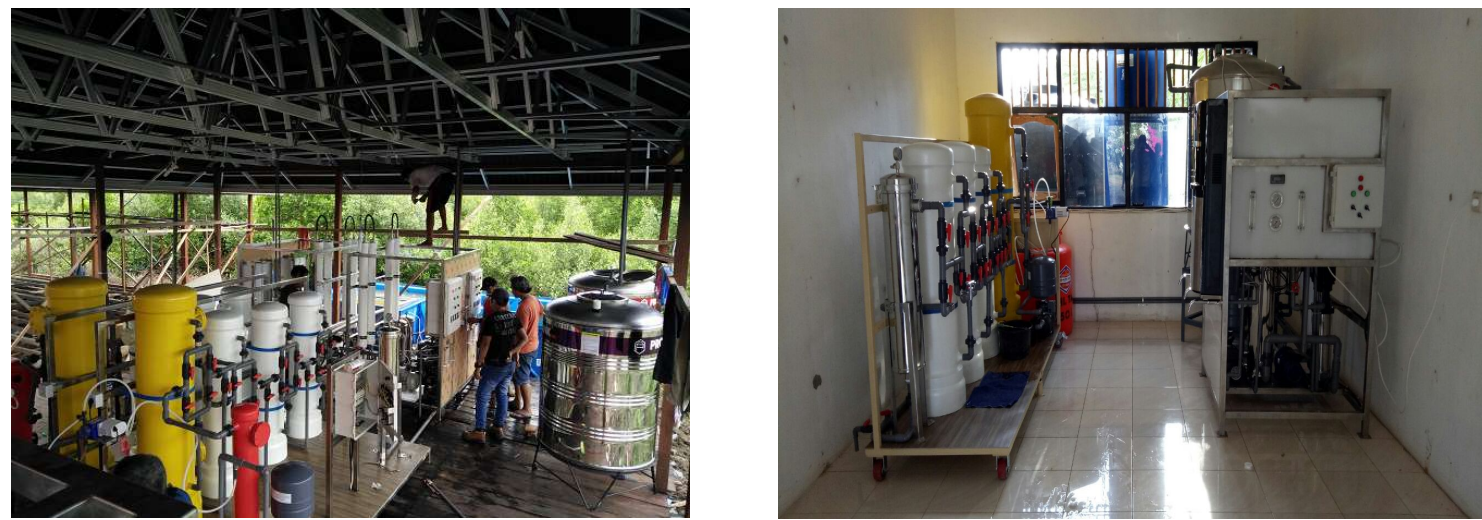

Gambar 11. Instalasi pengolahan air tanah yang tercemar air asin menjadi air minum.

Tabel 2. Biaya operasional produksi 10.000 liter/hari air minum

\begin{tabular}{|c|c|c|c|c|c|}
\hline \multirow{2}{*}{$\begin{array}{c}\text { No } \\
1\end{array}$} & \multirow{2}{*}{$\begin{array}{l}\text { Komponen pembiayaan } \\
\text { Bahan Bakar (solar) }\end{array}$} & \multicolumn{2}{|c|}{ Jumlah } & \multirow{2}{*}{$\begin{array}{c}\begin{array}{c}\text { Harga satuan } \\
\text { (Rp) }\end{array} \\
12.000,00\end{array}$} & \multirow{2}{*}{$\begin{array}{l}\text { Harga }(\mathrm{Rp}) \\
9.000 .000,00\end{array}$} \\
\hline & & 750 & Liter & & \\
\hline 2 & Bahan kimia $\mathrm{KMnO}_{4}$ & 1 & $\mathrm{~kg}$ & $12.000,00$ & $120.000,00$ \\
\hline 3 & Anti scalant & 0.5 & $\mathrm{~kg}$ & $40.000,00$ & $20.000,00$ \\
\hline 4 & Anti biofoaling & 0.5 & $\mathrm{~kg}$ & $40.000,00$ & $20.000,00$ \\
\hline 5 & Pengawet membran & 0.5 & $\mathrm{~kg}$ & $30.000,00$ & $15.000,00$ \\
\hline 6 & Media saringan manganese zeolit & 2 & $\mathrm{~kg}$ & $45.000,00$ & $90.000,00$ \\
\hline 7 & Media saringan karbon aktif & 4 & $\mathrm{~kg}$ & & $400.000,00$ \\
\hline 8 & Tenaqa Keria & 4 & orang & $\begin{array}{r}100.000,00 \\
3.200 .000\end{array}$ & 12800.000 .00 \\
\hline 9 & Tutup botol dan segel & 15.000 & buah & 200,00 & $3.000 .000,00$ \\
\hline 10 & Penggantian lampu ultraviolet dan seal & 2 & buah & $1.500 .000,00$ & $3.000 .000,00$ \\
\hline 11 & $\begin{array}{l}\text { Pemeliharaan, perawatan dan } \\
\text { kebersihan }\end{array}$ & 1 & bulan & $2.000 .000,00$ & $2.000 .000,00$ \\
\hline & $\begin{array}{l}\text { Total pembiayaan untuk produksi per } \\
\text { bulan }\end{array}$ & & & & $30.465 .000,00$ \\
\hline & Total pembiayaan per hari & & & & $1.015 .000,00$ \\
\hline & Biaya produksi air minum/liter & & & & $101,55,00$ \\
\hline & $\begin{array}{l}\text { Biaya produksi air minum/kemasan } \\
\text { galon }\end{array}$ & & & & $2.050,00$ \\
\hline
\end{tabular}


Tabel 3. Sekenario harga jual dan keuntungan

\begin{tabular}{cccccc}
\hline No & Asumsi penjualan & $\begin{array}{c}\text { Galon/ha } \\
\text { ri }\end{array}$ & & Keuntungan & \\
\hline & & $\begin{array}{c}\text { harga jual/galon } \\
\text { Rp. 3.500,00 }\end{array}$ & $\begin{array}{c}\text { harga jual/galon } \\
\text { Rp. 5.000,00 }\end{array}$ & $\begin{array}{c}\text { harga } \\
\text { jual/galon } \\
\text { Rp. 6.000,00 }\end{array}$ \\
\hline 1 & $\begin{array}{l}\text { Air minum terjual 100 } \\
\%\end{array}$ & 15.000 & $21.750 .000,00$ & $44.250 .000,00$ & 59.250 .000$, \\
& 11.250 & $16.312 .500,00$ & $33.187 .500,00$ & 44.437 .500 \\
2 & $\begin{array}{l}\text { Air minum terjual 75 } \\
\%\end{array}$ & $10.875 .000,00$ & $22.125 .000,00$ & 29.625 .000 \\
3 & $\begin{array}{l}\text { Air minum terjual 50 } \\
\%\end{array}$ & 7.500 & $11.062 .500,00$ & 14.812 .500 \\
\hline $\begin{array}{l}\text { Air minum terjual 25 } \\
\%\end{array}$ & 3.750 & $5.437 .500,00$ & 1000 \\
\hline
\end{tabular}

